\title{
Pobreza, igualdade e justiça social: republicanismo kantiano e contratualismo rawlsiano*
}

\author{
Poverty, equality and social justice: \\ Kantian republicanism and Rawlsian contractualism
}

DOI: $10.20873 / \mathrm{rpv} 6 \mathrm{n} 2-20$

\section{Vincenzo Maimone}

Orcid: 0000-0001-7607-1823

\begin{abstract}
Resumo
Pobreza, igualdade e justiça social voltaram à linha da frente do léxico político, econômico e social contemporâneo, embora de formas diferentes e com intensidade variável. A embriaguez do liberalismo e o entusiasmo injustificado pela dinâmica do mercado tinham projetado um mundo em que o bem-estar e a felicidade pareciam estar ao alcance de todos e totalmente disponíveis. Mas o despertar que se seguiu à loucura das finanças criativas nos entregou um cenário muito mais dramático e repleto de conflitos. Desse ponto de vista, a filosofia política não pode se eximir da tarefa de analisar esses fenômenos e definir um sentido e uma direção para a agenda política em tempos complicados como os atuais. É necessário, portanto, refletir novamente
\end{abstract}

\footnotetext{
* 0 tema deste artigo foi apresentado na Faculdade de Letras e Filosofia na Universidade de Buenos Aires, em 26 de novembro de 2019, em seminário organizado dentro do projeto "Kant in South America". Tal projeto recebeu financiamentos do Programa de Pesquisa e Inovação da União Europeia "Horizon 2020", no âmbito da convenção de subvenção Marie-Sklodowska-Curie n. 777786.

** Doutor em Filosofia pela Universidade Federal do Ceará (UFC) e pela Université de Lille. Professor de Filosofia da Universidade Federal do Tocantins (UFT).

*** Mestrando em Filosofia pela Università Gabriele D’Anunzio, Chieti - Pescara (Itália).
} 
sobre conceitos e perspectivas que talvez tenham sido descartados muito apressadamente. Neste artigo, pretendo examinar esses conceitos utilizando a relação controversa entre a filosofia kantiana e o contratualismo de John Rawls como um fio condutor.

\title{
Palavras-chave:
}

Equidade. Pacto social. Rawls. Kant.

\begin{abstract}
Poverty, equality, and social justice are terms that have forcefully returned to the fore, albeit with varying modalities and intensities, in the contemporary political, economic, and social lexicon. The liberal drunkenness and unjustified enthusiasm for the dynamics of the market had designed a world in which well-being and happiness seemed to be within everyone's reach and fully available. But the awakening following the revelry of creative finance has given us back a much more dramatic and conflictual scenario. From this point of view, political philosophy cannot exempt itself from the task of analysing these phenomena and defining a sense and direction for the political agenda in complicated times such as the present. It is therefore necessary to return to reflect on concepts and perspectives that are perhaps too hastily liquidated. In this article, I propose to examine these concepts using the controversial relationship between Kantian philosophy and John Rawls' contractualism as a guiding thread.
\end{abstract}

\section{Keywords}

Fairness. Social pact. Rawls. Kant.

\section{Pobreza e propriedade: a versão de Kant}

No senso comum, o termo pobreza indica uma carência, uma privação, natural ou induzida, de algo considerado necessário, ou, igualmente, a título funcional, a busca de um objetivo ou simplesmente de um instrumento útil para viver uma vida digna. A condição de pobreza, portanto, descreve e representa uma condição de inferioridade, um estado de desconforto que inibe a realização, a possibilidade de realizar plenamente a si mesmo, de realizar escolhas e de gozar de uma chance e de alguma oportunidade. Excluindo o caso limite da pobreza escolhida de forma consciente - imagine-se, nesse sentido, o ideal filosófico professado por Diógenes, o cínico, ou o modelo religioso pregado pelo franciscanismo -, a condição de privação determinada pela pobreza constitui um problema que requer soluções, seja em termos de superação do déficit social seja do déficit eminentemente econômico.

De todos os modos, a pobreza é um tema caro à política. Com efeito, a natureza política inerente ao conceito de pobreza pode ser deduzida a partir da própria definição que dela foi 
dada. Se, de fato, consideramos a pobreza como um estado de privação, de carência, eis que ela passa então a ser determinada pela falta de acesso ou pela negação de posse de um bem, qualquer que ele seja.

Nesse sentido a pobreza está estreitamente ligada a questões como a propriedade e os procedimentos ou a regras aptas a legitimá-la, e igualmente à natureza dos critérios adotados na distribuição de bens e recursos dentro de um contexto politicamente determinado.

Todavia, é importante sublinhar que reduzir o problema da justiça a uma mera questão de distribuição, ou de redistribuição, significa negligenciar um aspecto mais profundo que é inerente ao significado e ao papel da sociedade como um todo na sua complexidade. Poder-seia afirmar que a justiça distributiva seja um instrumento útil, mas não capaz de fornecer uma solução completa e plenamente satisfatória ao problema. Esse instrumento certamente sinaliza a sua existência, reduz as consequências, mas não se ocupa nem analisa as causas da sua origem.

Compreender a real natureza da pobreza significa, portanto, realizar uma pesquisa completa sobre a origem, a função e, sobretudo, acerca das obrigações jurídicas que decorrem da escolha de aderir ao pacto social original.

Para desenvolver essa perspectiva teórica, farei referência a um interessante opúsculo de Maria Julia Bertomeu, Pobreza y propiedad. ¿Cara y Cruz de la misma moneda? Una lectura desde el republicanismo kantiano. Nessa obra, Bertomeu desenvolve uma análise original sobre a relação entre pobreza e propriedade fazendo suas considerações a partir da perspectiva kantiana.

A pobreza, de fato, na interpretação kantiana feita por Bertomeu, não se configura como um problema inerente à justiça distributiva, mas representa uma questão que concerne à própria legitimidade de uma instituição e à natureza do vínculo da qual deriva. Um estado que não se ocupa ativamente em erradicar esse problema, carece de legitimidade e contradiz as razões subjacentes que permitiram o seu surgimento. 0 mesmo se pode dizer no caso em que uma instituição consinta a aquisição de propriedade com instrumentos e modalidades que não respeitem a reciprocidade que deve ser garantida no exercício da liberdade de todos. Aparece claramente já dessas poucas linhas introdutórias que o tema da pobreza, na leitura kantiana, ligase indissoluvelmente aos conceitos de liberdade (externa), de igualdade e de justiça social. Para 
compreender de maneira clara conceitos que se desenvolvem e interagem reciprocamente é útil fazer referência a uma passagem chave da Metafísica dos costumes, na qual Kant trata essa questão de modo explícito.

Segundo Kant, de fato:

Ao chefe supremo incube indiretamente, quer dizer, como alguém que assume o dever do povo, o direito de lançar sobre este certos impostos para a sua (do povo) própria conservação, tais como os que visam prover à assistência aos pobres, aos orfanatos e à igreja, instituições estas também chamadas de caridade ou pias.

A vontade universal do povo uniu-se, assim, com vista a uma sociedade que há-de conservar-se perpetuamente e submeteu-se ao poder estadual interno com o fim de prover à subsistência dos membros da sociedade incapazes de o fazer por si próprios. É, portanto, graças ao Estado que o governo tem legitimidade para obrigar os mais abastados a fornecer os meios de subsistência àqueles que o não conseguem fazer, nem sequer no que toca às necessidades naturais mais elementares; com efeito, a existência dos ricos é ao mesmo tempo um ato de submissão à proteção e ao provimento da comunidade, provimento a que se obrigam, e é nisto que o Estado funda o seu direito de obrigar os mais abastados a contribuir com o que é seu para a sobrevivência dos seus concidadãos. (KANT, 2018, p. 157-158 [2011, p. 199-200])*

É possível fazer diversas considerações em relação a esse trecho. Em primeiro lugar, é preciso corrigir imediatamente uma incompreensão. Sobre isso, concordo com Bertomeu quanto ao fato de a passagem kantiana não reduzir o problema inerente à eliminação da pobreza, liquidando-a em uma mera questão de beneficência, como um problema cuja solução seja possível recorrendo a voluntários atos de caridade por parte de pessoas economicamente independentes. 0 que Kant descreve, e tal referência não deixa espaço para interpretações ambíguas, é muito mais um dever jurídico, uma verdadeira e própria obrigação que vincula o soberano, na qualidade de "alguém que assume o dever do povo", e os "ricos", enquanto membros e parte daquela vontade geral legisladora que se constituiu no momento da adesão ao pacto original.

\footnotetext{
* Nas citações diretas de Kant e de Rawls, ao lado das referências às edições italianas utilizadas pelo autor, foram acrescentadas, entre colchetes, os dados de traduções em português, devidamente inseridas no elenco das referências bibliográficas ao final do artigo. [N.d.T.].
} 
Esse esclarecimento consolida a relação entre os conceitos de liberdade (externa) e de igualdade (no sentido jurídico de isonomia). E, portanto, não é à ideia de beneficência que Kant se refere, mas à noção de solidariedade.

Tal termo, muito frequentemente, é considerado de forma errada, como uma espécie de sinônimo de beneficência e, por isso, equiparado a ela; o ato de solidariedade é circunscrito às ações voluntárias e não sujeito a algum tipo de obrigatoriedade, muito menos jurídica. ${ }^{1}$

Na realidade, essa sobreposição constitui um erro, não só do ponto de vista linguístico, mas também na dimensão pública. De fato, para compreender em profundidade e de maneira inequívoca a noção de solidariedade, é preciso inseri-la no interior de uma moldura jurídica. Ser solidário significa assumir sobre si a obrigação jurídica (obligatio in solidum) do cuidado em relação aos membros da coletividade necessitada. Esse conceito remete à noção de responsabilidade e de coparticipação que são elementos essenciais na construção e na consolidação do pacto social. A adesão ao contrato implica reciprocidade e cooperação e vincula ao ônus da assistência - nisso consiste o apelo kantiano à obrigação de garantir a "conservação dos concidadãos".

Interpretada desse modo, a atenção à pobreza e à sua redução ou, como se espera, à sua eliminação, constitui uma espécie de evidência capaz de indicar o estado e a solidez do laço social. $\mathrm{O}$ objetivo de tal contrato, de fato, é a capacidade de exercitar a própria autonomia, de reivindicar a própria liberdade de agir, no respeito de uma recíproca e correspondente liberdade para todos os demais. Retomaremos mais adiante esse conceito cujo eco é reconhecível no âmbito do modelo elaborado por Jonh Rawls em Uma teoria da justiça.

De fato, seguindo a análise de Bertomeu, o laço jurídico e a reciprocidade do respeito das obrigações subscritas constituem o ponto nodal e a garantia do poder político, bem como consentem a plena afirmação da vontade geral legisladora.

A tal propósito, Bertomeu escreve:

Em um estado jurídico, os governantes recebem um mandato derivado de um dever do povo que os habilita a exercer seu direito de cobrar impostos monetários para a manutenção de quem, no povo, não são capazes de cobrir as suas necessidades naturais. Esse dever, e seu correspondente direito

\footnotetext{
${ }^{1}$ Sobre esse argumento, veja-se SCIACCA, 2018; HABERMAS, 1996 e 1997 e MAIMONE, 2009.
} 
delegado - brotam de uma vontade geral que se uniu na sociedade com o fim de lograr sua própria manutenção. E é essa a razão pela qual é um dever do povo sair do estado de natureza e entrar no estado jurídico, como ato de aceitação de uma coação (recíproca) destinada a garantir o direito à liberdade externa inata de todos. (BERTOMEU, 2017, p. 481)

Ao contrário, é precisamente a excitação sobre a mera beneficência, entendida como instrumento de voluntarismo, útil para atenuar as condições de carência dos mais fracos que denota, para Kant, a traição do pacto original. Paradoxalmente, é a partir de uma injusta e, portanto, por isso mesmo ilegítima, distribuição originária da propriedade, que os que gozam de maiores fortunas podem se mostrar publicamente altruístas e generosos. A beneficência, se construída sobre tais pressupostos, se manifesta como um estigma, uma velada confissão de culpa. Sobre esse tema, a beneficência se revela como um fruto envenenado oferecido aos pobres por um governo injusto e por isso mesmo ilegítimo, porque lesivo da liberdade entendida como direito inalienável. Obviamente, dessa crítica fica excluído o ato de beneficência não viciado por semelhante anomalia distributiva. Tal ação generosa realizada com coração sincero determina no beneficiado uma obrigação (moral) de reconhecimento. Kant desenvolve amplamente essa perspectiva na segunda parte da Metafísica dos costumes, analisando a doutrina da virtude.

Escreve a esse propósito:

A capacidade de praticar a beneficência, que depende dos meios de fortuna, é na sua maior parte uma consequência de certos homens terem sido favorecidos pela injustiça do governo, que introduz uma desigualdade de situação patrimonial que torna necessária a beneficência de outros. Em tais circunstâncias, merecerá verdadeiramente o auxílio que o rico possa prestar aos necessitados o nome de beneficência, de que de tão bom grado aquele se vangloria, como se de um mérito se tratasse? (KANT, 2018, p. 323 [2011, p. 400])

Para que se possa sanar a injustiça decorrente da desigualdade gerada por atos juridicamente desconformes, é preciso refazer o correto procedimento de aquisição, de tal modo que sejam respeitadas as cláusulas fundamentais sobre as quais se rege a república pura kantiana, ou especificamente, o respeito pela liberdade da desigualdade inata.

De fato, assim afirma Bertomeu (2018, p. 487-488): 
O estado jurídico (ou república pura kantiana) não só é o garante da liberdade (a independência com respeito ao poder constritivo do outro desde que possa coexistir com a liberdade de qualquer outro sujeito segundo uma lei universal), a não ser que também da igualdade inata entendida como a capacidade de todos de obrigarem-se reciprocamente, e de se tornar um homem íntegro (iusti), integridade entendida juridicamente como não se deixar espezinhar o direito inato e possuir a capacidade de impedir ser tratado por outros como um mero meio.

A condição de necessidade determinada pelo estado de pobreza, portanto, se configura como uma situação na qual o sujeito necessitado corre o risco de ser degradado a mero objeto, a coisa, a meio funcional à consecução de um fim que não lhe pertence. Tal condição de dependência se encontra em clara oposição ao status de cidadão, condição essa adquirida pela adesão ao pacto e à inclusão na vontade geral legisladora. A desigualdade, determinada por atos desconformes às leis prescritas pelo governante do Estado, enquanto titular do poder executivo e na qualidade de agente do Estado, constitui uma violação das regras que pressupõem a distinção e a legítima atribuição da propriedade.

No contexto do Estado de direito, como Kant o concebe, de fato, subsistem três espécies de objetos sobre os quais o sujeito pode exercitar legitimamente o próprio arbítrio:

1. Uma coisa (corpórea) fora de mim; 2.0 arbítrio de outrem em relação a um determinado ato (praestatio); 3. 0 estado de outrem em relação a mim; isto é, segundo as categorias da substância, da causalidade e da comunhão entre mim e os objetos exteriores, segundo leis de liberdade. (KANT, 2018, p. 58 [2011, p. 70-71])

Tal passagem confirma não só a tese kantiana segundo a qual o estado de dependência consequente da perda da própria autonomia, em razão da violação da liberdade e da igualdade inata, determina uma ruptura profunda no fundamento do estado jurídico e, além disso, define de maneira precisa os âmbitos nos quais é possível considerar legítima a posse. Segundo Kant, de fato, é possível reivindicar tal direito seja em relação a coisas corpóreas seja em relação a outros objetos. Em ambos os casos, de qualquer modo, a existência de leis e a sua necessária observância delimita a modalidade de posse e a extensão de tal reivindicação. No que concerne ao arbítrio exercido sobre outros indivíduos, ou em razão de um contrato de prestação, ou em relação a um estado jurídico, como, por exemplo, o matrimônio e a posse da prole, tais contextos não podem contemplar a anulação total da autonomia subjetiva. Kant aprofunda esse aspecto 
na Metafísica dos costumes. 0 elemento constante dessa análise permanece sempre o mesmo, a autonomia, o direito de exercitar livremente a própria liberdade (externa, mas também interna) constitui a referência na república kantiana.

O Estado de direito concebido por Kant é, portanto, caracterizado por um sistema jurídico no qual os membros aceitam uma recíproca coação. Um sistema no qual a liberdade de todos é possível justamente, e por nada paradoxalmente, em razão de recíprocas limitações. Trata-se de uma espécie de equilíbrio em constante ajustamento entre a necessidade de salvaguardar ilícitas interferências à autonomia pessoal deliberativa - no respeito da liberdade negativa - e a necessidade de uma moldura jurídica suficientemente estável, capaz de evitar toda forma de abuso ou de prevaricação. Como sublinha Arthur Ripstein em Force and Freedom, analisando a questão relativa à justiça penal no pensamento kantiano, a transgressão representa a tentativa - ilícita - de um sujeito de substituir uma decisão unilateral pela escolha omnilateral que emoldura o pacto social e que se exprime através da vontade geral do legislador.

Em termos gerais, a injustiça consiste na violação de qualquer título da lex iusti, ou da ideia de justo que fundamenta e alimenta as instituições.

Trata-se só aparentemente de uma consideração tautológica. Nesse sentido, o que Kant reivindica é a impossibilidade de justificar a violação de uma regra com motivações morais ou a partir de um cálculo de utilidade e de um potencial benefício derivante da transgressão.

Em uma perspectiva puramente deontológica, como é a kantiana, uma violação, mesmo realizada em vista de um bem, permanece como ato ilegítimo, e por isso, condenável.

Permaneci nessa digressão porque o primado do Justo sobre o Útil representa um dos elementos de semelhança entre a concepção kantiana e o modelo teórico rawlsiano no qual, é preciso lembrar, "a justiça constitui a primeira virtude social das instituições políticas”. Mais adiante retornaremos a essa questão. Por enquanto, aprofundamos a perspectiva kantiana e algumas passagens propedêuticas para completar a análise feita até aqui.

Foi dito que a relação recíproca entre a liberdade e a ausência geral e unânime em relação a uma recíproca coação representam o eixo fundamental do estado jurídico kantiano e definem, em alguma medida, também as coordenadas do que podemos chamar de vida honesta.

A esse propósito Bertomeu sublinha como: 
Desde um ponto de vista jurídico, então, o "viver honestamente" significa o dever jurídico interno (uma auto-coação) de respeitar minha própria liberdade interna entendida como a capacidade de ser um sujeito de direito próprio, quer dizer, de manter a própria independência frente ao arbítrio constritivo do outro: e precisamente na medida em que a própria liberdade "pode coexistir com a liberdade de qualquer outro segundo uma lei universal” (BERTOMEU, 2017, p. 492).

0 contínuo apelo à necessidade de salvaguardar e de garantir o livre exercício do sui iuris constitui, portanto, uma constante no âmbito da reflexão kantiana. É claro que tal concepção não se move até as suas extremas potencialidades, ou melhor, a propriedade de si, não se estende também à propriedade da, ou sobre a, vida. Nesse sentido, Kant é um homem do seu tempo, e assim, tal questão representa ainda hoje um argumento controverso capaz de alimentar acaloradas discussões. Todavia, o dado central dessa referência contínua é o papel desempenhado pela ideia de propriedade. Tal aspecto pertence, portanto, não só à aquisição de bens materiais, a possibilidade de exercer o arbítrio sobre as coisas, como acenamos antes, mas também à possibilidade da própria autoafirmação.

Essa perspectiva constitui o núcleo central da ideia de republicanismo da qual Kant se faz intérprete. Segundo Bertomeu, de fato, é possível afirmar que essa interpretação do papel e da função da propriedade coloca Kant dentro dessa tradição de pensamento político.

Na tradição republicana histórica na qual Kant autoconscientemente se encontra, a estrutura institucional da propriedade tem efeitos incontestáveis para o gozo da liberdade externa, para a cidadania e também para a legitimidade do estado. Entre outras coisas, porque a propriedade é vista como controle e garantia de uma existência social autônoma, porém também porque a liberdade é considerada um direito constitucional inalienável. Nessa tradição, a propriedade é entendida como controle sobre o recurso possuído, e esse controle confere independência política e personalidade jurídica própria. Trata-se - para dizer com uma bela expressão do Marx republicano - da propriedade que permite o desenvolvimento da "livre individualidade" e floresce quando o trabalhador (artesão) é proprietário dos instrumentos de produção o quando o pequeno camponês se encontra em posse da terra que trabalha. (BERTOMEU, 2017, p. 496)

Mais incisivamente, Bertomeu enfatiza como:

Nessa tradição, a independência que confere a propriedade não é um assunto de mero interesse privado, mas de grande importância política, tanto para o exercício da liberdade como para a realização do autogoverno republicano. Pois ter uma base material assegurada é indispensável para a própria independência e competência políticas. E nessa tradição a liberdade é inalienável, o que significa que é um direito "constitutivo" distinto dos "instrumentais", que não posso vendê-lo ou presenteá-lo e que estão regulados pelo direito público: não posso vender meu direito à vida e muito menos partes 
do meu corpo, não me é permitido celebrar contratos privados de escravidão voluntária, nem tampouco são permitidos os contratos laborais privados indeterminados no que se refere ao tempo e ao trabalho (locatio conductio operarum). (BERTOMEU, 2017, p. 497)

Também nesse caso, e é uma das razões pelas quais me detive sobre essa longa citação, é detectável a presença de alguns elementos temáticos que podemos encontrar no contexto do modelo rawlsiano. Refiro-me, de modo particular, à ideia de propriedade como instrumento de autopromoção política e ao valor inalienável da liberdade. No que concerne ao primeiro elemento é necessário focar na primeira parte da citação.

De fato, segundo o que foi dito, a propriedade não é considerada a razão do valor monetário, por assim dizer, que ela possui, mas sim pela função política que é chamada a desempenhar. Graças a ela, o sujeito pode gozar da própria autonomia: pode ser livre e defender-se de qualquer forma de prevaricação e constrição. Aliás, é graças à propriedade, em um sentido político mais amplo e geral, que se pode iniciar determinados processos que conduzem à "realização do autogoverno republicano".

Esse argumento é retomado por Rawls em Teoria da justiça. Com efeito, Rawls insere a propriedade entre as liberdades fundamentais que o primeiro princípio da justiça é chamado a tutelar. Tal referência, contrariamente ao que foi afirmado por alguns críticos desatentos, não é ditada pela exigência de promover uma noção liberal de sociedade fundada sobre o jogo cataláctico de oferta e procura. Ao contrário, as razões pelas quais, segundo Rawls, a propriedade privada deva ser considerada entre as liberdades fundamentais, é que através dela é possível limitar, conter o risco de sofrer, ou de dever ceder a formas coercitivas - no sentido kantiano discutido até aqui -, de domínio. Trata-se de um elemento essencial que permite distinguir o paradigma rawlsiano do contrato social de outros modelos, os quais, ao contrário, consideram a possibilidade de impor ameaças como prerrogativa útil na estratégia de contratação das instituições públicas. ${ }^{2}$

A propriedade é, portanto, um instrumento essencial para a autonomia e para a liberdade. Podemos obter uma ulterior confirmação a respeito da qual deve ser a correta

\footnotetext{
${ }^{2}$ Sobre esse argumento veja-se GAUTHIER, 1986.
} 
interpretação da propriedade no contexto da obra rawlsiana naquilo que o autor define como regra da propriedade. Tal concepção se conecta com o segundo elemento que é possível extrair da citação feita antes.

O inalienável valor da liberdade representa um aspecto constitutivo e não negociável. Isso significa que por nenhum motivo pode ser limitado ou cedido a outros. Essa restrição fundamental serve para salvaguardar os indivíduos do risco de submeter-se a uma forma de escravidão voluntária. Em Rawls, a regra da prioridade desempenha expressamente essa função. Ao ordenar lexicograficamente os dois princípios de justiça: o princípio de liberdade e o princípio de diferença, Rawls introduz uma importante cláusula, a regra de prioridade. Tal regra estabelece que o primeiro princípio deve ser sempre considerado prioritário em relação ao segundo. Isso quer dizer claramente que a liberdade não pode ser trocada ou limitada em razão de um maior bem-estar econômico. E tal vínculo não concerne somente à arquitetura das instituições - não representa apenas um vínculo para aqueles que administram e exercem o poder político -, mas também influencia e regula as relações privadas entre os cidadãos. A razão pela qual tal regra é introduzida é a proteção das instituições da lenta degradação ao longo da escorregadia via do interesse, público e privado. 0 bem-estar não constitui o fim político de uma instituição duradoura e estável, de uma sociedade bem ordenada. A liberdade, sublinha Rawls, pode ser limitada somente em nome da própria liberdade. Com tal velada expressão, deseja-se fazer referência à dialética interna, às dinâmicas e às interseções entre direitos e liberdade na estreita arena das liberdades fundamentais.

Nesse sentido, o caso ilustrado por Bertomeu constitui um dos exemplos possíveis de violação da regra de prioridade e da tentativa de reduzir a autonomia individual apoiando-se sobre a capacidade de ameaçar e sobre o estado de dependência de determinados sujeitos.

Ainda devemos desenvolver um último aspecto em relação a essa primeira parte.

Até o momento, de fato, sublinhamos muitas vezes a relação entre a liberdade e a propriedade, chamando a atenção para a necessidade de reivindicar, individualmente, o respeito e a observância de tal prerrogativa, ou simplesmente reforçando a existência de uma obrigação, que poderemos definir, política, de corrigir a desigualdade derivante de uma desconforme aquisição da propriedade. 
Mas, então, a partir de qual argumentação é possível justificar a modificação da relação entre o teu e o meu, para usar a terminologia kantiana?

Em outros termos, é preciso atentar para o processo genealógico da propriedade, para as suas origens e as modalidades nas quais ela pode ser considerada legítima. Trata-se de um argumento politicamente relevante, estreitamente ligado ao problema da desigualdade. Se, de fato, assim como afirmamos outras vezes, é da ilegitimidade da posse que decorre a desigualdade, então é preciso pressupor que existiu um momento no qual essa distorção teve início. E, consequentemente, antes de tal ruptura, o estado no qual viviam os indivíduos devia ser caracterizado por uma condição de igualdade natural, pois não era sustentado por leis e procedimentos considerados vinculantes. Trata-se do momento genético que determina não somente a passagem da igualdade para a desigualdade, mas também a passagem de uma condição pré-política para uma dimensão política. Tal condição implica, logicamente, a propriedade coletiva dos bens e dos recursos.

Nessa linha, a perspectiva adotada por Kant retoma, diversas vezes, a tese ilustrada por Locke no Segundo tratado sobre o governo. De acordo com essa reconstrução, Deus doou o mundo aos homens que, portanto, o possuíam originariamente de maneira coletiva e igual.

A passagem da propriedade coletiva à propriedade privada se tornou legítima através do recurso de uma particular forma de aquisição que autoriza tal transação: o trabalho. Segundo Locke, de fato, é possível considerar o trabalho como uma extensão do próprio corpo. A legitimidade da aquisição inicial deriva, portanto, da aplicação de uma espécie de propriedade transitiva entre o próprio corpo, o trabalho (entendido como sua extensão) e o mundo externo. Tal posse, todavia, ainda seguindo o modelo de Locke, está sujeita a algumas importantes limitações (clausulas limitativas lockeanas): consistem na possibilidade de cada um exercer essa transição e, consequentemente, na obrigação de deixar à disposição da coletividade uma quantidade de bens e de recursos suficiente e igualmente boa para satisfazer as exigências de todos e consentir a cada um realizar os próprios objetivos.

A concepção kantiana move-se dentro do modelo de Locke. Com efeito, também para Kant, a aquisição originária não pode ser deixada ao livre arbítrio de cada um, mas deve responder àquela obrigação jurídica da reciprocidade e da coação que existe na raiz das 
instituições políticas. Por isso mesmo, no estado jurídico kantiano, na república pura kantiana, o controle por parte do Estado dos mecanismos de aquisição da propriedade e a possibilidade de intervir e corrigir toda distorção constituem uma prerrogativa essencial e totalmente legítima. Esse aspecto, precisamos reforçar, concluindo essa sessão, não se reduz a um mero procedimento de justiça distributiva, mas é inerente à estrutura fundamental das instituições e à sua razão de existir.

\section{0 paradigma rawlsiano: a importância de um modelo}

A teoria da justiça como equidade elaborada por John Rawls ocupa um lugar central no âmbito do debate filosófico político contemporâneo. Essa afirmação já constitui uma verdade autoevidente, não obstante os anos transcorridos desde a sua primeira formulação e independentemente das críticas que durante esse tempo submeteram o modelo a revisões, correções, recuos parciais e, sobretudo, modificaram inclusive a composição de grupos diferentes e opostos. A teoria de Rawls, de fato, caracterizou a discussão, não só acadêmica, ao longo de cinquenta anos. Na verdade, o cálculo do tempo leva em conta o longo trabalho preparatório realizado pelo filósofo americano antes da publicação da versão definitiva da obra. Nesses cinquenta anos, os cenários, nacionais e internacionais, mudaram, e não necessariamente para melhor, mas a urgência e a necessidade de dar respostas plausíveis e substancialmente praticáveis a questões fundamentais que concernem à existência dos indivíduos, permaneceu a mesma. 0 cenário global que hoje se apresenta aos nossos olhos considera de maneira inequívoca essa urgência e determina, ao mesmo tempo, a necessidade de reabrir o debate sobre questões essenciais: pobreza, igualdade, justiça social, direitos e inclusão, só para limitar o elenco às questões mais urgentes. A desatenção para com esses temas, cujas causas são diversas e variamente complexas, produziu como resultado um mundo profundamente injusto e abalado por conflitos. A ilusão da mão invisível, a falsa crença de já se viver em um mundo completamente pacificado, em suma, toda a retórica fundada sobre fantasiosos operadores das altas finanças determinou uma condição global muito próxima do colapso. 
Em relação a isso, retornar aos temas filosófico-políticos rawlsianos significa assumir o ônus de procurar uma sólida solução para problemas e questões que incidem profundamente sobre as escolhas e sobre o destino dos indivíduos.

Foi dito, introduzindo o tema deste parágrafo, que a obra de Rawls constitui um marco, um verdadeiro divisor de águas no contexto da reflexão filosófica e política. Este mérito decorre de uma série de fatores. Em primeiro lugar, a proposta teórica de Rawls interrompeu o monopólio do paradigma utilitarista que havia dominado a cena pública até aquele momento e que, sobre esse argumento, havia reduzido a discussão em torno da natureza e da função das instituições a um mero problema de eficiência dos critérios de alocação. Tal abordagem se limitava a identificar o justo ponto de equilíbrio entre custos e benefícios sem prestar particular atenção aos indivíduos, considerados como entidades complexas e não homologáveis ou redutíveis a simples agentes racionais interessados unicamente em maximizar o trade off das escolhas individuais. Uma visão como essa, de fato, se fundava sobre uma descrição padronizada e insatisfatória tanto dos sujeitos quanto das modalidades de seleção das opções disponíveis.

É a partir dessa consideração geral que Rawls desenvolve a sua teoria, operando uma verdadeira mudança de paradigma nas modalidades de abordagem e de atuação da escolha tanto em termos individuais quanto naqueles coletivos. 0 utilitarismo não representava mais a única opção politicamente atuável. Mas para justificar essa repentina mudança de estratégia, era necessário reconfigurar todo o sistema e apresentar um novo e convincente procedimento deliberativo.

Analisar a obra de Rawls significa, portanto, considerar seriamente a modalidade de seleção dos critérios e dos princípios que ordenam e regulam as decisões públicas e privadas, em um contexto político e por instituições que queiram garantir estabilidade duradoura e respeitar os direitos e as liberdades próprias de uma sociedade bem ordenada.

Reassumir a teoria de Rawls não é de forma alguma simples. Seria possível afirmar que tal empreendimento não seja possível. A matriz analítica que serve de quadro teórico torna difícil encontrar atalhos expositivos. 0 risco ao qual nos dirigimos é a banalização do modelo ou a perda de vista do fim último e do escopo fundamental que o sistema filosófico rawlsiano quer realizar. Muitas das críticas levantadas ao projeto da justiça como equidade carregam esse 
defeito. Repetiremos esse argumento mais adiante, por ora procederemos a apresentação da estrutura fundamental da proposta rawlsiana.

Rawls introduz o tema da sua obra de modo direto e sem giros de palavras inúteis. A justiça constitui a primeira virtude social de uma instituição política e, acrescenta, assim como ocorre para os sistemas de pensamento nos quais uma teoria, mesmo elegante e cativante, deve ser abandonada se não for verdadeira, do mesmo modo é preciso reformar e modificar uma instituição se essa não realiza o fim último da justiça.

Mas o que Rawls pretende exatamente? Ao que se refere quando introduz o tema da justiça? E ainda: por que precisamos de semelhante ideia?

\subsection{As perguntas fundamentais da filosofia política}

Para compreender plenamente as motivações que formam o pano de fundo da proposta de Rawls, é preciso uma breve digressão cujo objetivo é determinar o âmbito no qual desenvolveremos nossa análise teórica e no qual a própria proposta rawlsiana se move.

Essa digressão pertence ao conjunto daquelas que, com eficaz expressão, o filósofo político Salvatore Veca definiu como perguntas fundamentais da filosofia política. Estes quesitos, de fato, constituem o cenário principal no qual operam e a partir do qual devem ser avaliadas as teorias filosófico-políticas. Trata-se de dilemas que empenham as instituições e aos quais precisamos responder, quer os aceitemos como parte do nosso próprio modelo organizacional, quer discordemos deles e desejemos refutá-los.

Tais perguntas podem ser expostas assim:

1. “É justo que pessoas nasçam ricas ou muito ricas e outras pobres ou muito pobres?"

2. “Em que sentido preciso são erradas desigualdades que não são culpa dos indivíduos que as sofrem?"

3. "As instituições políticas devem fazer algo, empenhar seus recursos de autoridade, decidir escolhas coletivas para procurar reduzir desigualdades desse tipo, pelas quais as vítimas não são responsáveis?" (cf. VECA, 1998) 
Um aspecto geral que emerge confrontando-se com tais dilemas é que toda resposta possível não pode ser considerada politicamente neutra. Dito de outra forma, o modo em que estes nós políticos são desfeitos define e caracteriza a conotação política, podemos dizer a ideologia, adotada como critério para a identificação dos instrumentos políticos úteis para a sua solução. E tal aspecto não constitui necessariamente um limite, aliás, ao contrário, ele permite evitar continuar emaranhados no limo da transversalidade política e da hipocrisia reformista, aspectos que caracterizam muitas das abordagens contemporâneas nas análises das questões públicas.

0 primeiro quesito representa um indicador fundamental em tal sentido.

Isso implica uma resposta sobre o papel que ser atribuído ao que Bernard Williams definia como a sorte moral que caracteriza cada indivíduo na construção das instituições básicas e na definição dos critérios de acesso e de fruibilidade da cidadania comum. Em outros termos, o quesito demanda estabelecer se o êxito contingente da loteria natural e social deva influenciar no reconhecimento político dos membros de uma sociedade; se tais temas devam ocupar algum espaço no contexto da agenda política. 0 modo no qual nos dispomos diante de tal interrogação define as características fundamentais do critério de inclusão social que visa adotar como base para a participação política e sugere, também, qual deva ser a função das instituições diante de tais desigualdades.

Com o termo loteria natural se entende o conjunto dos fatores contingentes como habilidade, talentos, desabilidade dos quais cada indivíduo é dotado, de maneira inteiramente arbitrária, ao nascer. 0 termo loteria social, ao contrário, se refere às características igualmente contingentes e fortuitas, devidas às condições sociais nas quais cada indivíduo é posto no momento do seu nascimento. Em termos gerais, adotando uma perspectiva existencialista, é possível afirmar que cada sujeito se encontra jogado em um mundo que não escolheu e com características definidas pela pura e simples casualidade. Kant, por exemplo, adota um argumento que pode ser aproximado ao que descrevemos analisando a relação e as obrigações atribuídas aos pais diante da prole.

O cenário no qual os sujeitos se movem é caracterizado pela presença de desigualdades, às vezes evidentes e profundas, que incidem de maneira decisiva sobre as escolhas, as opções, 
a esperança de sucesso e, logo, sobre a própria possibilidade de levar uma vida digna de ser vivida.

Existem três atitudes possíveis diante desses dilemas. A primeira abordagem é aquela que parte de uma radical recusa da relevância da sorte moral em questões de justiça.

Em tal contexto, afirmar que o primeiro quesito não configura uma questão de justiça significa confiar ao acaso e à pura sorte todo destino individual. É inteiramente evidente, de fato, que uma solução fatalista implica a libertação de toda forma de intervenção social voltada a corrigir e limitar os danos produzidos pela arbitrariedade da natureza. Tal abordagem parte de uma interpretação da igualdade que podemos definir natural. Segundo essa perspectiva, de fato: 1) existe o acaso; 2) esse determina de maneira imponderável o lugar que ocuparemos no contexto da sociedade; 3) tal atribuição arbitrária de talentos e possibilidades como também de obstáculos e dificuldades não é ligada a nenhum mérito individual; mas, 4) precisamente por isso, à desigualdade que decorre de tal loteria não pode ser ligada nenhuma responsabilidade pública, e, portanto, 5) as instituições não devem se encarregar de sanar as desigualdades introduzindo mecanismos corretivos que, ao contrário, imporiam injustamente custos sociais que incidiriam negativamente sobre liberdades e sobre direitos individuais.

A indiferença em relação ao primeiro quesito, portanto, leva logicamente a respostas negativas aos outros dois dilemas.

A segunda abordagem possível responde a uma perspectiva moderada e disposta a considerar em alguma medida a questão e a encarregar-se, ao menos em parte, das desigualdades decorrentes da arbitrariedade de nascimento. Trata-se de uma solução parcial, mas exatamente como a primeira, igualmente insatisfatória. Esta perspectiva, mesmo reconhecendo a contingência e a incidência da loteria natural e social na definição das chances e das oportunidades individuais considera como dignas de uma intervenção pública só aquelas desigualdades atribuíveis a distorções produzidas por comportamentos sociais. Além disso, o modo pelo qual tais diferenças são remediadas se limita a uma abordagem formal, por exemplo, através da concessão do livre acesso a carreiras e posições independentemente do status social ocupado. Tal estratégia se insere no contexto teórico do chamado igualitarismo liberal. Também nesse caso a responsabilidade da coletividade inerente ao estado de carência e à falta de iguais 
oportunidades para alguns membros da sociedade é relativa e de qualquer forma não deve alterar o status e o aparato distributivo vigente. E ainda, o que determina a mobilidade dentro da sociedade é o livre jogo do mercado e a construção espontânea do equilíbrio entre custos e benefícios e entre procura e oferta.

Enfim - a abordagem que descreve e conota a perspectiva rawlsiana - a tal dilema pode ser dada uma resposta convincente e inteiramente negativa, isto é, não condiz com critérios de justiça o fato de que um ato arbitrário como o nascimento determine êxitos e possibilidades diametralmente opostos entre os indivíduos.

Dito de outro modo, tal atitude política, mesmo reconhecendo a arbitrariedade que caracteriza a loteria natural e social, sustenta a subsistência de uma responsabilidade coletiva indiferenciável. Essa responsabilidade deriva do compartilhamento do mesmo espaço social e da própria natureza do laço que está na base das relações intersubjetivas que caracterizam as instituições políticas. Ser membro de um corpo coletivo, de uma sociedade política, implica a aceitação de ônus reciprocamente vinculantes. No espaço público compartilhado, então, não é pensável que a cidadania comum seja distinguível sobre a base de uma gradualidade que determine as possibilidades de inclusão e que influencie sobre os êxitos e sobre o destino dos indivíduos de forma inteiramente contingente e não publicamente justificável.

Uma abordagem assim parte do álveo do igualitarismo democrático. Nessa perspectiva, a função das instituições políticas será promover iniciativas e definir os critérios de alocação de bens e de recursos, de chances e de oportunidades para corrigir não só formalmente, mas de modo substancial, as desigualdades presentes dentro da sociedade decorrentes de distorções arbitrárias e imerecidas.

Essa concepção, sob certos aspectos, se justapõe à interpretação kantiana apresentada no início deste artigo. A obrigação social que a igualdade democrática pressupõe, de fato, decorre do compartilhamento do espaço público e da aceitação recíproca do pacto social. A cidadania comum implica igual respeito e a observância de um princípio de subsidiariedade pelo qual as instituições devem se encarregar.

É a partir dessa consideração geral e sobre essa interpretação da desigualdade que é possível perceber a originalidade e a natureza inovadora do contrato rawlsiano. 


\subsection{Uma teoria da justiça}

Foi dito que a justiça constitui, para Rawls, a primeira virtude social. Tal primado coloca a concepção rawlsiana em um contexto deontológico, no qual o Justo representa um elemento, um valor, prévio a toda concepção diferente e independente da concepção ou das concepções de Bem presentes nos limites da esfera pública. Todavia, é preciso pontuar que a ideia de justiça analisada por Rawls coincide com a equidade (fairness). É em razão dessa justaposição, de fato, que o horizonte igualitário dentro do qual opera tal concepção é aquele democrático em que a justiça distributiva ocupa um lugar fundamental na construção das condições otimais para o exercício do direito de cidadania e para poder viver uma vida digna de ser vivida.

Porém, é importante precisar, retomando algumas considerações desenvolvidas no parágrafo dedicado à interpretação kantiana, que, como em Kant, também para Rawls a justiça distributiva não constitui o fim último ou a máxima representação do empenho deontológico em favor de uma sociedade justa. Com efeito, também para Rawls o problema da distribuição não se identifica com uma mera questão de eficiência burocrática privada de significado e de relevância política. A correção das distorções e das desigualdades está estritamente relacionada com a natureza bem ordenada da sociedade. Poderíamos dizer que essa representa um elemento constitutivo para uma instituição que queira dizer-se livre e democrática e que procure a Justiça como ideal.

Uma vez esclarecido esse aspecto, é oportuno agora voltar a atenção às características estruturais, por assim dizer, da sociedade rawlsiana.

O objetivo que Rawls pretende alcançar e que explicita em maneira clara introduzindo os temas gerais da sua teoria e definindo os contornos teóricos dentro dos quais o modelo se move é levar ao mais alto nível de abstração possível a ideia da sociedade como fruto de um contrato social, sobre a base do que já foi afirmado por Locke, Rousseau e Kant.

Para tanto, Rawls pontua ainda mais incisivamente qual seria o principal objetivo desse procedimento de escolha coletiva.

Para isso, não devemos achar que o contrato social tem a finalidade de inaugurar determinada sociedade ou de estabelecer uma forma específica de governo. Pelo contrário, a ideia norteadora é que 
os princípios de justiça para a estrutura básica da sociedade constituem o objeto do acordo original. (RAWLS, 1989, p. 27 [2008, p. 13])1

Esse esclarecimento é extremamente relevante, pois não apenas fornece um importante instrumento interpretativo útil a orientar-se dentro do modelo rawlsiano, mas introduz um dos temas que mais tem alimentado a discussão crítica em torno da teoria da justiça. A busca do protótipo de instituição compatível com a teoria da justiça como equidade, de fato, pode ser considerada como um dos desafios intelectuais abertos pela perspectiva contratualista de Rawls. Tal busca gerou não apenas equívocos e mal-entendidos em relação ao problema da avaliação do caráter - liberal, social-democrática, socialista -, do modelo institucional privilegiado por Rawls; mas gerou também uma longa série de discussões sobre a historicidade ou a-historicidade da tese contratualista promovida pela perspectiva rawlsiana. ${ }^{3}$ Sobre isso, tal mal-entendido é o resultado de uma incorreta interpretação do trecho citado acima.

Deixarei deliberadamente em suspenso esse enigma sobre o qual voltaremos mais adiante, tão logo sejam descritas de maneira detalhada as características essenciais do procedimento deliberativo elaborado por Rawls.

Foi dito que a teoria da justiça como equidade orbita em torno do paradigma contratualista.

Nesta perspectiva, a sociedade representa o produto de um procedimento contratual. Isso significa que a passagem de uma condição pré-política a um estado político, no qual regras, princípios e leis sejam objeto de um acordo coletivo, é sancionada pela natureza convencional e artificial que sustenta semelhante instituição. Portanto, uma sociedade política não surge espontaneamente, com a boa paz dos defensores do liberalismo clássico à la Hayek, mas é o resultado de uma escolha esperançosamente consciente e racional.

A análise rawlsiana, então, enfrenta em primeira instância as características e as modalidades através das quais se efetua essa escolha.

\footnotetext{
${ }^{3} \mathrm{O}$ problema da falta de uma dimensão histórica caracterizou numerosas objeções nos confrontos do modelo rawlsiano. Agnes Heller, por exemplo, desenvolveu a sua análise crítica justamente a partir de tal carência e das consequências que dela derivam na construção do procedimento deliberativo através do qual se definem os princípios básicos. Sobre isso, veja-se HELLER, 1990.
} 
A pergunta que forma o pano de fundo dessa sessão da teoria é a seguinte: “Quais princípios seriam selecionados por indivíduos racionais, em dadas condições de escolha, como princípios básicos de uma sociedade bem ordenada?".

Dentro dessa interrogação, estão condensados os elementos fundamentais do modelo. 0 primeiro aspecto que se deve enfrentar é aquele inerente às condições da escolha. Sobre isso, é importante distinguir dois diferentes âmbitos. Em primeiro lugar, deve-se identificar as condições que tornam necessário um procedimento deliberativo como o proposto. Essas correspondem àquelas que Rawls define, tomando em empréstimo a expressão de Hume, circunstâncias de justiça. Em segundo lugar, uma vez compreendidas as razões que tornam necessário o acordo, será possível voltar a atenção às modalidades e aos procedimentos que deverão regular o contrato.

Com o termo circunstâncias de justiça, entende-se o conjunto das condições que tornam necessária a introdução de alguma concepção do Justo. Para esse propósito, Rawls distingue duas diferentes tipologias, a saber: circunstâncias de justiça objetivas e circunstâncias de justiça subjetivas.

As primeiras pertencem às condições externas, ou seja, ao contexto dentro qual os indivíduos agem e interagem. Tais circunstâncias, portanto, definem as características gerais da dimensão pré-política, pondo o acento antes de tudo na disponibilidade dos recursos. Sobre isso, Rawls sublinha que o contexto dentro do qual as partes são chamadas a realizar a seleção dos princípios básicos é caracterizado por uma condição de escassez moderada de bens e de recursos. Isso significa que a quantidade de recursos disponíveis para a coletividade é suficiente para garantir uma vida digna, mas para que isso seja possível é preciso introduzir algum critério de distribuição.

De modo mais simples, a quantidade de recursos disponíveis se coloca em uma posição intermediária entre uma condição de abundância e de plena disponibilidade - que em termos estritamente lógicos tornaria supérflua toda concepção da justiça: pois, em tal sociedade da abundância, cada membro teria à disposição tudo o que deseja sem o risco de ter que competir com outros sujeitos pela legitimação da posse -, e uma condição de extrema pobreza na qual, 
do mesmo modo, um critério de justa distribuição se revelaria não só inútil, mas ineficaz, pois, em semelhante contexto, a pura contingência dominaria e determinaria as decisões.

As segundas, as circunstâncias de justiça subjetivas, definem a atitude, as motivações que impulsionam as partes a buscar um acordo com outros sujeitos. Na interpretação de Rawls, a identikit psicológica das partes corresponde àquela dos sujeitos caracterizados por um egoísmo moderado. Isso significa que, por um lado, eles são movidos pela vontade de satisfazer ao máximo possível os próprios desejos e aspirações; mas, por outro lado, são conscientes de que a natureza interdependente do contexto e a disponibilidade moderada dos recursos tornam necessária uma mediação em termos de expectativas e resultados que possam ser perseguidos. Também nesse caso, a posição ocupada pelos sujeitos pode ser posta em um domínio intermediário entre uma condição de egoísmo radical, de um lado, a qual, evidentemente, frustraria ex ante a possibilidade de um acordo. Em um mundo povoado por sujeitos radicalmente egoístas não seria possível nenhum tipo de mediação e a única forma de contrato seria aquela fundada sobre a capacidade de ameaça ou sobre a mera ação da força. E a caracterizada, do outro lado, por uma situação de altruísmo radical. Mas como o próprio Rawls sublinha, em uma comunidade de santos, como se configuraria aquela que acabamos de descrever, a justiça não teria razão de ser.

O egoísmo moderado que caracteriza as partes pode ser justaposto, nesse jogo de busca das similitudes kantianas, à concepção descrita por Kant como sociabilidade insociável.

No ensaio Ideia de uma história universal do ponto de vista cosmopolita, introduzindo a Tese Quarta, Kant fornece uma descrição extremamente clara da natureza humana e da ambivalência que caracteriza as relações intersubjetivas:

Entendo aqui por antagonismo a sociabilidade insociável dos homens, isto é, a sua tendência para entrarem em sociedade, tendência que, no entanto, está unida a uma resistência universal que ameaça dissolver constantemente a sociedade. Esta disposição reside manifestamente na natureza humana. 0 homem tem uma inclinação para entrar em sociedade, porque em semelhante estado se sente mais como homem, isto é, sente o desenvolvimento das suas disposições naturais. Mas tem também uma grande propensão a se isolar, porque depara ao mesmo tempo em si com a propriedade insocial de querer dispor de tudo ao seu gosto e, por conseguinte, espera resistência contra os outros. (KANT, 1995, p. 127 [2008, p. 24]) 
Uma vez definidas as circunstâncias da justiça, é possível voltar a atenção às modalidades pelas quais as partes escolhem. No contexto da teoria rawlsiana, a questão procedimental ocupa um lugar de destaque. A ideia de fundo é que a correta definição dos critérios de escolha coletiva, tanto em termos substanciais quanto em termos meramente formais, produzirá como consequência lógica êxitos igualmente corretos. Rawls define esta modalidade de deliberação como construtivismo kantiano. Trata-se de um exemplo emblemático de justiça procedimental pura. Dito de outro modo, a aplicação ponderada dos critérios e dos vínculos deliberativos torna supérfluo um ulterior controle sobre a correção do êxito. Além disso, e tal aspecto constitui uma primeira resposta parcial ao dilema inerente ao modelo institucional privilegiado pelo contratualismo rawlsiano, tal procedimento, de fato, alarga o leque das opções institucionais praticáveis. Portanto, a forma do Estado não é um elemento determinante, mas, ao contrário, a correta atuação dos procedimentos deliberativos através dos quais são edificados os fundamentos de uma sociedade bem ordenada.

Ora, ao analisar tal processo de seleção é útil atentar para alguns elementos fundamentais.

A primeira questão a se enfrentar é aquela relativa à composição da assembleia deliberativa. Quem são os atores chamados a definir a moldura institucional da sociedade rawlsiana? Sobre isso, seguindo a descrição de Rawls, as partes, ou seja, os indivíduos racionais encarregados de selecionar os princípios básicos, são os agentes representantes de todas as posições sociais relevantes no contexto de uma sociedade. Referindo-se a elas, Rawls as descreve como pessoas morais livres e iguais e lhes atribui duas características essenciais, dois poderes morais: a capacidade de possuir um senso de justiça e a capacidade de conceber alguma concepção de bem. 0 primeiro desses poderes, de acordo com a perspectiva kantiana, dá conta do laço de reciprocidade que subsiste entre os membros da assembleia deliberativa e que, consequentemente, caracterizará as relações intersubjetivas no contexto da sociedade construída à luz do pacto assinado. De fato, todo indivíduo que compõe a assembleia, baseando-se sobre do senso de justiça, se empenha em respeitar as decisões deliberadas e sabe que os outros também o farão. Tal característica constitui uma precondição essencial para que a ideia de sociedade 
enquanto resultado de um procedimento de contrato tenha algum sentido e uma chance de levar a êxitos politicamente praticáveis.

O segundo poder moral atribui aos sujeitos a capacidade de conceber alguma concepção de bem. Essa possibilidade leva em conta o fato de que a dimensão moral, mesmo ocupando uma posição periférica, por assim dizer, durante as fases de debates da assembleia, constitui um possível ponto de referência na reflexão dos agentes em fase de deliberação.

Todavia, Rawls, em razão das restrições impostas às partes durante a fase da deliberação - aspectos sobre os quais nos deteremos mais adiante - distingue entre uma teoria sutil do Bem (thin theory) e uma teoria espessa (thick theory). Com a primeira expressão, ele se refere a uma definição muito ampla e podemos dizer genérica do Bem. As partes podem, em certo sentido, delinear os contornos de uma perspectiva moral, mas não estão em condições de descrever as suas características específicas. Neste sentido, a dimensão moral constitui um dos critérios de avaliação da força dos princípios, mas não representa o parâmetro fundamental pelo qual tal escolha é, enfim, aperfeiçoada.

Tal aspecto apresenta alguns nós problemáticos que foram realçados por mais de uma voz crítica.

Nesse sentido, é preciso assinalar como essa parte da teoria foi sucessivamente remodelada por Rawls em razão de uma longa série de objeções. Tais modificações confluirão em Liberalismo político, a obra de 1993, na qual o autor procura responder às críticas inerentes à capacidade do seu modelo teórico de considerar de forma devida o pluralismo como fato politicamente relevante.

A segunda questão a se analisar é relativa à particularidade das condições introduzidas por Rawls no contexto do procedimento deliberativo.

As partes, de fato, se encontram naquela que Rawls define como posição original (original position). 0 filósofo, a tal propósito, observa que este contexto deliberativo deve ser entendido como um artifício expositivo útil para considerar a natureza particular do acordo que as partes estão prontas para assinar. Portanto, a posição original constitui um tipo de estado de natureza (mas utilizo essa expressão de modo extremamente cauto). Nessa, a assembleia 
deliberativa composta pelas partes é chamada a discutir e a decidir com voto unânime quais princípios deverão ser postos como fundamento da sociedade bem ordenada da qual farão parte.

Para aguçar a natureza geral, o caráter universalista da escolha, Rawls põe os agentes da deliberação sob um véu de ignorância. As partes deverão selecionar os princípios básicos sem conhecer alguns elementos particulares relativos à sua vida, às suas crenças, sem qualquer informação que possa influenciar a sua decisão. Tal vínculo ao conhecimento unido à necessidade de um acordo unânime são instrumentos deliberativos cuja finalidade é evitar que a escolha seja viciada por formas mais ou menos óbvias de domínio, cultural ou social, por exemplo, ou permita a indivíduos ou a grupos mais ou menos amplos desfrutar de uma vantagem de ameaça no âmbito do contrato. 0 véu de ignorância permanece enquanto não se chega a uma escolha unanimemente aprovada.

Rawls, então, adotando esta solução pretende revirar as características que com frequência são consideradas como expressões de uma escolha racional, ou seja, um pleno conhecimento dos elementos relevantes. Neste contexto, ao contrário, é precisamente a falta de informações que permite a busca do objetivo no seu máximo grau.

Qual é a razão inerente a essa preferência metodológica?

Para compreender o sentido dessa decisão, é preciso realçar um aspecto, muitas vezes negligenciado na abordagem interpretativa da obra rawlsiana. Rawls quer representar em Uma teoria da justiça a realização de um procedimento constitutivo. Em relação a isso, de fato, os princípios de justiça constituem apenas as bases constitucionais sobre as quais deve se erguer todo tipo de sociedade que aspire a ser livre e democrática, que respeite a dignidade, os direitos e as liberdades fundamentais dos seus membros e que esteja em condições de garantir uma justa igualdade de oportunidades independentemente das diferenças determinadas pela sorte e pelo contexto social.

É em razão dessa finalidade precisa que o momentâneo ocultamento dos conhecimentos se revela como útil recurso para promover uma decisão razoável e racional capaz de garantir às instituições uma estabilidade duradoura. A disponibilidade de informações ou a prevalência de sentimentos irracionais ou de paixões conflitivas (o azar ou a inveja, para nos limitarmos a dois 
exemplos emblemáticos) prejudicariam a busca de tal fim deliberativo. A neutralização desses elementos perturbadores representa, assim, o artifício expositivo fundamental para uma decisão razoável. As partes, então, fazem a própria escolha procurando identificar uma mediação compartilhada entre os próprios juízos ponderados à luz dos dois poderes morais à sua disposição e das consequências gerais das quais são dotados, e a ideia geral de justiça que deverá formar o pano de fundo à sociedade bem ordenada. Também nesse caso, a tentação de criar um paralelismo com a perspectiva kantiana é muito forte. Com efeito, é possível, a meu ver, justapor esse procedimento ao exame kantiano relativo ao imperativo categórico. As partes, de fato, deverão determinar se os seus juízos ponderados (as suas máximas) podem ser unanimemente aprovados como concepção geral da justiça (imperativo categórico). O que domina nessa modalidade deliberativa não é uma razão estratégica ou funcional à busca de interesses parciais e contingentes, antes, o escopo é a construção de uma base institucional razoável e compartilhável de forma duradoura. Tal processo de harmonização toma o nome de equilíbrio reflexivo e leva em conta a natureza razoável dos agentes da deliberação.

Mas quais são as opções disponíveis? A função das partes, devemos precisar tal aspecto, não é aquela de esboçar tais princípios. Deverão limitar-se a escolhê-los em um elenco já dado de opções possíveis. Tal elenco reproduz aqueles princípios que formam o pano de fundo das principais teorias políticas, econômicas e sociais: anarquismo, liberalismo, libertarismo, socialismo, visões perfeccionistas da sociedade, concepções utilitaristas da alocação dos recursos. Em suma, todos os cenários político-institucionais possíveis estão representados no elenco posto à disposição da assembleia. ${ }^{4}$

Cada uma dessas opções é submetida ao crivo das partes, as quais, na completa escuridão no que concerne às informações relevantes, escondidas delas pelo véu de ignorância e sobre a base dos próprios juízos ponderados, deverão selecionar a alternativa que, uma vez obtido o voto unânime por parte da assembleia, definirá as características fundamentais das instituições básicas da sociedade. É importante recordar que a escolha feita pela assembleia, deliberada de forma unânime, não é reversível. Esse caráter definitivo, unido à falta de

\footnotetext{
4 Para uma descrição detalhada das alternativas disponíveis, veja-se RAWLS, 1989, p. 115-116.
} 
conhecimentos específicos, constitui uma sorte de ulterior incentivo a realizar uma seleção oportunamente ponderada. Nesse sentido, o funcionamento do teste de aceitabilidade dos princípios, o critério adotado individualmente pelas partes poderia ser sintetizado nestes termos: cada membro da assembleia deliberante é chamado a avaliar as consequências que a adesão a uma determinada configuração institucional comportaria, à luz dos possíveis cenários definidos pela contingência da loteria natural e social e consciente de que não será possível modificar a escolha uma vez aprovada. É então esse o critério de racionalidade adotado como critério de comparação da decisão. Trata-se de um procedimento que não restringe a liberdade de escolha - todas as opções estão igualmente disponíveis -, mas que age sobre a responsabilidade individual e sobre a capacidade de realizar uma avaliação em uma perspectiva temporal alargada. Em termos de racionalidade da escolha, as partes deveriam imaginar a sua posição social, econômica ou política consequente à aplicação dos princípios, de tempos em tempos testados, como se se encontrassem ocupando, por efeito de uma desastrosa sorte moral, o plano mais baixo da estrutura social. Trata-se de um teste em que prevalece uma forte atitude cautelosa (uma atitude excessivamente cautelosa, segundo alguns comentadores). Rawls define tal critério deliberativo utilizando a expressão, maximin. Tal termo constitui a síntese da frase: maximum minimorum, ou seja, as partes, dadas as condições nas quais é feita a escolha, serão levadas a selecionar aqueles princípios cuja aplicação lhes garantiria o melhor resultado (maximum) dado o pior êxito da loteria natural e social (minimorum).

\subsection{Os princípios de justiça}

À luz dessas considerações, racionais e prudenciais, a preferência das partes - é esta a conclusão de Rawls - concordaria com os dois princípios de justiça: 1) o princípio da máxima igual liberdade e 2) o princípio da justa igualdade de oportunidade.

Na sua formulação definitiva, tais princípios podem ser assim enunciados:

Primeiro princípio:

Cada pessoa deve ter um direito igual ao mais abrangente sistema total de liberdades básicas iguais que seja compatível com um sistema similar de liberdade para todos; 


\section{Segundo princípio:}

As desigualdades econômicas e sociais devem ser dispostas de modo a que:

Se estabeleçam para o máximo benefício possível dos menos favorecidos que seja compatível com as restrições do princípio de poupança justa, como;

Estejam vinculadas a cargos e posições abertos a todos em condições de igualdade equitativa de oportunidades. (RAWLS, 1989, p. 255 [2008, p. 376])

Os dois princípios são lexicalmente ordenados e, como afirmado antes, o primeiro princípio é prioritário em relação ao segundo. Isso quer dizer que só se poderá proceder a aplicação do segundo princípio depois de plenamente garantidas, formal e substancialmente, as liberdades fundamentais.

A razão de fundo que subjaz à regra de prioridade é que o bem-estar econômico não pode nunca ser considerado uma moeda de troca à custa dos direitos e das liberdades fundamentais.

Trata-se de um esclarecimento extremamente importante no contexto da perspectiva rawlsiana. A tutela prévia de um sistema total de liberdades fundamentais, de fato, tem o escopo precípuo de consentir que todos os sujeitos, na qualidade de membros plenamente reconhecidos da sociedade, participem do debate público em condições de substancial igualdade, que façam valer as próprias razões e vivam uma vida digna de ser vivida protegidos de qualquer constrição e do risco de dever permutar a própria autonomia em razão de uma maior cota de bens ou recursos. De fato, é através da tutela e da promoção de tais liberdades que é possível exercitar o direito à igual cidadania.

A esse respeito, pode-se afirmar que a igualdade política constitui uma precondição indispensável ao surgimento de uma sociedade bem ordenada.

Todavia, isso não implica que a questão do acesso a bens e recursos e, portanto, a redução das dificuldades econômicas e sociais determinadas pelo fenômeno da pobreza seja, por Rawls, posto em segundo plano ou simplesmente confiado às dinâmicas do mercado em uma moldura econômica dominada pelo paradigma capitalista.

Na realidade, o que decorre da aceitação das teses da justiça como equidade é exatamente o contrário. Analisando com a devida atenção as premissas e as conclusões expostas por Rawls, nós nos damos conta, com certa evidência, obscurecida apenas em razão de uma 
interpretação superficial ou incorreta, que nem as teses neoliberais ou libertárias, nem o entusiástico otimismo nos confrontos das capacidades taumatúrgicas do livre mercado, têm estatuto dentro da perspectiva rawlsiana. 0 apelo e o primado à ideia de justiça representam um balanço de referência institucional que nada tem a ver com o desempenho e com a indiferença política libertária em relação aos últimos.

Para reforçar ulteriormente essa leitura da tese neocontratualista rawlsiana é útil pôr o acento sobre o papel adscrito ao princípio de diferença. Tal princípio define um nítido distanciamento, no contexto da reflexão que determinou a gênese de Uma teoria da justiça, da concepção, à época dominante, da função das instituições. 0 objetivo de Rawls é interromper um velho hábito, segundo o qual a eficiência alocativa constituía o critério primário na avaliação de todo aparato institucional. 0 monopólio da eficiência paretiana, de fato, não estava em condições de responder de modo satisfatório às exigências de justiça e de equidade que derivam da tomada de consciência e do reconhecimento da existência de desigualdades muitas vezes não observadas ou consideradas com fatalista superficialidade. Segundo o modelo paretiano, toda mudança em dada configuração distributiva pode ser considerada legítima se, e somente se, nenhum dos sujeitos concernidos sofrer perdas na transição do primeiro ao segundo aparato distributivo. Dito de outro modo, a curva de eficiência na passagem da primeira à segunda distribuição deverá ser crescente para todos. Rawls contesta, portanto, a força do critério de distribuição subjacente a essa abordagem, ou seja, segundo a interpretação paretiana, uma distribuição é correta se, e somente se, representar "vantagem para todos". Para compreender sobre quais razões se apoia a crítica rawlsiana, é suficiente voltar a atenção para a discrição e para a incidência que a arbitrariedade da loteria natural e social exerce sobre os destinos, sobre as chances e sobre as oportunidades individuais. Foi dito que tais desigualdades não apenas são imerecidas, mas, no contexto de uma sociedade bem ordenada, livre e democrática, essas determinam uma responsabilidade institucional pela recuperação de uma condição de equidade e de igualdade das oportunidades. E, então, uma distribuição justa pode implicar que a curva de alocação não deva ser necessariamente crescente para todos. Posta nesses termos, a teoria de Rawls substitui o critério "em favor de todos" pelo critério "em favor dos menos favorecidos". 
É sobre essa base que uma distribuição desigual satisfaz as razões da justiça, como primeira virtude social.

A preferência de Rawls pela equidade parte, de fato, da consideração de que nem sempre uma distribuição igual se revela como uma distribuição justa. A especificidade dos destinos individuais, a casualidade dos pontos de partida existenciais, representam variáveis cuja influência sobre as possibilidades, sobre a sorte subjetiva, não pode ser resolvida por uma mera divisão em partes iguais. 0 significado profundo da ideia de equidade consiste então em levar a sério não só os direitos dos indivíduos, mas também as suas histórias, a sua biografia, a sua sorte moral pessoal.

E tal aspecto, come se exprime no segundo princípio de justiça, não diz respeito só à atribuição de bens e de recursos, mas, dá conta da função e do papel político que cada sujeito é chamado a desempenhar dentro das instituições (cargos e posições abertos a todos). Tal responsabilidade não se exaure no arco de uma geração. Dito de outra forma, a função dos princípios de justiça não é proporcional ao aqui e agora, antes, se desvenda no tempo e entre as gerações. 0 apelo ao respeito do princípio de poupança justa, de fato, absorve exatamente essa tarefa. Isso é responsável pelo fato de que a teoria de Rawls não se propõe exclusivamente como modelo de justiça intrageracional, mas, ao contrário, aspira a ser um modelo capaz de absorver e de responder de maneira satisfatória às exigências e à necessidade de justiça e de equidade intergeracional.

Nesse sentido, é suficiente deter-se sobre a animada discussão contemporânea em torno de questões ambientais para compreender a extrema atualidade e a necessidade de retomar o debate sobre a justiça social. A nossa irracional leviandade, a falta de responsabilidade, com que as gerações presentes estão dilapidando os recursos naturais e econômicos são clara manifestação da incapacidade de elaborar uma concepção de sociedade capaz de ir além da mera contingência e de promover projetos e legitimar expectativas de longo prazo. Uma sociedade que não decida deixar nada além de terra arrasada às futuras gerações.

A estabilidade duradoura de uma sociedade, isto é, o fortalecimento do cimento social, se dá pelo modo em que o substrato constitucional, fundado sobre os princípios básicos, se vivifica e se traduz em direito positivo. 
Essa passagem, no contexto da teoria da justiça de Rawls, se concretiza em uma fase sucessiva à unânime deliberação em torno dos princípios. Tal fase é chamada de sequência de quatro estágios. Nessa, assistimos não só a um progressivo desbaste da espessura do véu de ignorância, a uma recuperação por parte dos membros da assembleia deliberativa, na qualidade de cidadãos plenamente reconhecidos pela sociedade bem ordenada, das informações completas sobre o próprio status, gênero, perspectivas morais ou religiosas, visões de mundo etc.; mas também a uma tradução dos princípios de justiça em direito positivo e em práticas concretas. A sequência de quatro estágios, portanto, define as linhas que guiam e indicam o percurso que permite a conversão do modelo teórico em uma práxis aplicável a uma sociedade democrática em pleno funcionamento.

Nesse sentido, os princípios de justiça rawlsianos constituem uma referência constante, o papel de tornassol através do qual uma sociedade pode perpetuar-se e renovar-se dinamicamente dentro de uma concepção do Justo razoavelmente compartilhada.

\section{0 suspeito de sempre: procurando Rawls}

Demorei bastante sobre a descrição detalhada de algumas das passagens teóricas fundamentais do neocontratualismo rawlsiano. Esta opção metodológica não se justifica apenas pela natureza analítica desse modelo, cujos mecanismos internos são estritamente conectados em um equilíbrio extremamente delicado que não admite atalhos, mas também pela necessidade de iluminar o campo da discussão acadêmica contemporânea inerente aos temas da filosofia política, de uma tradição interpretativa superficial acerca da proposta teórica rawlsiana.

Uma teoria da justiça, foi dito repetidamente, determinou um importante salto conceitual, uma mudança de paradigma, parafraseando Kuhn, no contexto da reflexão filosófico-política contemporânea. Ela caracterizou um debate profícuo e, sob muitos aspectos, estimulante, que não só permitiu a elaboração de novas perspectivas teóricas, mas consentiu que a própria teoria se testasse e esclarecesse aspectos ainda obscuros ou passíveis de interpretações ambíguas. Sobre isso, basta observar a cronologia bibliográfica rawlsiana para compreender como boa parte do empenho intelectual do filósofo americano posterior à publicação da obra de 1971, 
foi profuso para responder, rever e esclarecer a sua proposta teórica. Mas - e é precisamente deste "mas" que agora se deve partir em toda esta espasmódica busca de uma interpretação clara e inequívoca - subsiste uma marca, uma sorte de verdadeiro estigma que parece assinalar ainda hoje o modelo teórico rawlsiano. Para compreender a natureza de tal crítica é importante lembrar que o impacto intelectual da teoria da justiça como equidade não disse respeito exclusivamente à fria e distante reflexão acadêmica. 0 contratualismo rawlsiano e o apelo à centralidade institucional da justiça social como fonte de estabilidade e de promoção das liberdades e dos direitos individuais, de fato, representou um estímulo fundamental no contexto do processo de reformação que animou o pensamento progressista a partir da metade dos anos setenta. A repentina mudança do cenário geopolítico internacional exigia novos pontos de referência, uma abordagem diferente das urgentes questões inerentes às reivindicações sociais, à luta de classes em um mundo que dia após dia se inebriava sob o efeito das exaltantes perspectivas capitalistas. Buscava-se uma nova gramática através da qual fosse possível declinar uma diferente, mas inclusiva, proposta política.

Nesta perspectiva, o apelo à equidade e o destaque dado por Rawls à urgência de remediar as desigualdades arbitrárias determinadas pela contingência natural e social representavam, para muitos, um ponto de referência, a possibilidade concreta de um novo início.

No entanto, contrabalançando esta abertura a uma concepção que remodelou o papel e a natureza intrínseca das instituições, tomando a sua deixa a partir de uma tradição consolidada de pensamento, se coloca uma espécie de desconfiança generalizada e de relutância suspeita que caracteriza tanto as críticas a Rawls provenientes da direita libertária como aquelas vindas da esquerda radical. Para os primeiros, o filósofo americano deu uma credibilidade inaceitável à perspectiva social-democrática (demasiado progressista para se autodefinir liberal); para os segundos, ao contrário, Rawls procurava impor o modelo do mercado como solução à luta de classes (liberal demais para definir-se progressista).

O limite intrínseco de tal abordagem, independentemente da direção de origem da crítica, é concentrar o esforço intelectual na tentativa ilusória de mostrar o que Rawls não é, mais do que empenhar-se em buscar compreender a fundo o conteúdo e as características da sua proposta. 
O que pretendo contestar neste parágrafo não é a legitimidade da crítica, mas a tendência superficial a liquidar um modelo a partir de uma perspectiva de observação incorreta.

Para esse fim, farei referência a um ensaio que, sob muitos pontos de vista, encarna essa tradição crítica. Com efeito, em El Republicanismo y la crisis del rawlsismo metodológico, María Julia Bertomeu e Antoni Domènech analisam as ditas promessas traídas pelo modelo rawlsiano, usando como critério de interpretação a crise do rawlsianismo metodológico. Com esta expressão, tomada em empréstimo de Norman Daniels, deseja-se fazer referência à atitude filosófica, àquela perspectiva teórica voltada à construção de modelos institucionais que, partindo de algumas diferentes premissas rawlsianas, procuram remediar as distorções decorrentes dos critérios adotados nos procedimentos de alocação de bens e recursos e em alguma medida se propõem a harmonizar as dinâmicas econômicas com as instâncias da justiça social.

A ideia parece ser então aquela de sustentar a tese segundo a qual a ineficácia do modelo rawlsiano seja demonstrável em razão da debilidade teórica dos seus epígonos. Esse é só o primeiro dos três pilares sobre os quais se rege essa crítica indireta à teoria da justiça como equidade.

O outro elemento de dissenso é identificável no foco adotado pelos autores, que, mesmo reconhecendo o indubitável papel inovador de Rawls, findam por reduzir o seu quadro teórico a uma simples defesa do modelo neoliberal. É a tese de que na construção rawlsiana prevalece o desejo de fornecer alguma justificativa à economia de mercado. Para sustentar essa interpretação, Bertomeu e Domènech utilizam como termo de comparação a solução teórica proposta por Ronald Dworkin. Há um evidente erro de fundo nesta estratégia. De fato, se por um lado é certamente possível colocar Dworkin dentro daquele movimento filosófico-político de certo modo ligado ao debate aberto pela teoria da justiça como equidade; por outro, todavia, a solução proposta por Dworkin apresenta notáveis diferenças, no mérito e no método, da perspectiva rawlsiana. Mesmo se tanto Dworkin quanto Rawls levam a sério a questão dos direitos e, sobretudo o conceito de igualdade ligado à correção da distribuição (de recursos ou de oportunidades), no entanto, o tipo de abordagem e de justificativa adotada por Dworkin não é compatível com as premissas rawlsianas. A teoria da igualdade elaborada por Dworkin, de fato, compreende dois momentos fundamentais. O seu escopo é tanto reduzir a disparidade garantindo 
uma igualdade de recursos, quanto promover a liberdade dos sujeitos na busca dos próprios objetivos sobre a base da concepção pessoal do que dá, ou que deveria dar, valor a uma vida.

O primeiro momento, sintetizando ao máximo a sua abordagem, parte da ideia segundo a qual uma distribuição pode dizer-se correta se, e somente se, não determinar sentimentos de inveja, quer dizer, alimentar o desejo de obter o cesto de bens e recursos possuído por outros sujeitos concernidos na distribuição. Para superar esse problema, o filósofo estrutura a modalidade de desenvolvimento dessa ideal alocução inicial como uma escolha coletiva realizada através de uma série de ajustamentos e correções na composição destes cestos ideais. A distribuição terminará assim que cada parte estiver totalmente satisfeita e não considerar oportuno alterar o conteúdo do seu cesto. Após esta fase inicial, os sujeitos poderão livremente decidir como utilizar os recursos postos à sua disposição, baseando-se na sua concepção do mundo, na sua perspectiva moral e na sua atitude perante o risco. Nesse sentido, a relação entre as instituições e os sujeitos é determinada pelo modo em que tais significados se traduzem em ações e escolhas efetivas. A atitude diante do risco se torna, neste contexto, um instrumento útil para determinar as modalidades de uso dos recursos disponíveis. Segundo Dworkin, o problema das desigualdades produzidas pelas dinâmicas sociais poderia ser resolvido transferindo aos indivíduos o ônus da escolha do grau de cobertura "social" da qual pretendem usufruir no caso de a sorte se revelar adversa. 0 sistema de seguros concebido por Dworkin parte dessa concepção. A escolha que os sujeitos podem livremente realizar depende da avaliação pessoal da sua preferência. A distância entre essa abordagem e o princípio de diferença rawlsiano é flagrante e não carece de ulteriores aprofundamentos. 0 papel das instituições no âmbito da perspectiva delineada por Rawls não é acessível ao Conselho de administração de uma companhia de seguros. A desigualdade é um problema político, porque subtrai vozes e espaços à participação pública, determina sujeições e cria condições para formas de domínio inaceitáveis em um contexto que pretende considerar a justiça como primeiro valor.

Posto nesses termos, o exemplo adotado por Bertomeu e Domènech resulta inapropriado. 
O terceiro pilar sobre o qual os autores constroem a sua crítica pode ser enunciado a partir do elenco das quatro características típicas daquelas teorias que se aproximam do rawlsismo metodológico.

Segundo Bertomeu e Domènech (2005), tais traços podem ser descritos assim:

1) Nível de abstração;

2) Âmbito de aplicação dos problemas normativos;

3) Conceito das circunstâncias da justiça;

4) Instrumentos conceituais neoclássicos.

Estas características se desenvolvem ao redor de um mesmo elemento de dissenso, quer dizer, da ideia de que o paradigma rawlsiano, e por osmose, também os seus possíveis derivados, seja viciado por uma perniciosa a-historicidade que tira força teórica ao modelo e o impede de qualquer tradução prática. Um excesso de abstração que desvanece os contornos da subjetividade e da especificidade dos agentes deliberantes torna anônima e indistinta toda decisão. Sobre algo diversamente semelhante se fundava a crítica comunitarista de Sandel que contestava, em O liberalismo e os limites da justiça, a estranheza dos contratantes e a natureza desenraizada do eu rawlsiano (cf. SANDEL, 1994).

Neste contexto, segundo Bertomeu e Domènech, os problemas inerentes à composição e ao papel das instituições, da democracia, do respeito recíproco e da capacidade individual e coletiva de elaborar alguma concepção específica da vida boa, passariam para segundo plano em razão de um primado da justiça distributiva em relação às outras instâncias. Mesmo a descrição das circunstâncias de justiça iria de encontro ao mesmo defeito estrutural. Diferentemente do que é defendido por Hume, do qual, como se disse, o filósofo traz a expressão, as circunstâncias de justiça descritas por Rawls não resultariam de uma atenta análise da situação histórico-contingente, mas se limitariam a uma abstrata generalização. Nesse contexto, o recurso a modelos interpretativos das trocas e da distribuição de bens e de recursos representaria a enésima tentativa de creditar um tipo de valor universal e incontestável às relações fundadas sobre a livre troca e sobre o confronto entre procura e oferta como critérios de estabilização aplicáveis a bens e recursos, mas também aos destinos e às escolhas individuais. 
Em relação a essa objeção, me limitarei a reiterar como a escolha realizada por Rawls decorre da natureza constitucional que caracteriza a sua perspectiva neocontratualista. As partes simbolizam os membros de uma assembleia constituinte e os princípios que são chamados a definir devem poder ser razoavelmente aplicados independentemente da contingência da situação. Como Rawls reafirmou em Liberalismo político, a seleção dos princípios não é acessível a um modus vivendi, um provisório compromisso ditado pelas razões contingentes em conflito. A força das instituições é dada pela capacidade de fornecer indicações razoáveis e publicamente compartilhadas que garantam uma estabilidade duradoura.

Isso não quer dizer que todo modelo institucional possa ser compatível com essa descrição geral. A generalidade da abordagem não suporta a indiferença na seleção dos cenários políticos. Os princípios de justiça não podem ser desvalorizados como meros passe-partout. Os critérios de aceitabilidade que esses justificam delimitam, de fato, o âmbito de aplicabilidade concreta. Como os próprios autores reconhecem, Rawls desatou esse nó em Justiça como equidade. Uma reformulação (cf. RAWLS, 2002). Repetidamente solicitado por estudiosos e críticos, Rawls declarou explicitamente como os modelos institucionais que melhor se harmonizam com os princípios de justiça são aqueles acessíveis a uma democracia de cidadãos proprietários e a uma socialdemocracia. ${ }^{5}$ Ao mesmo tempo, Rawls muitas vezes rejeitou a justaposição da sua teoria a alguma forma de instituição fundada sobre uma concepção forte e invasiva do mercado. O libertarismo compassivo representa, nesse sentido, uma escolha totalmente incompatível com a concepção da justiça como equidade e com a ideia de igualdade democrática que essa pressupõe e promove.

Uma última reflexão toca a solução levantada por Bertomeu e Domènech como resposta à crise do rawlsianismo e às promessas não mantidas pela perspectiva contratualista. Os autores propõem a retomada e a reavaliação daquilo que Pocock definia como o momento maquiaveliano. A ideia de fundo promovida pela perspectiva republicana é aquela de substituir a liberal e desencarnada concepção de lealdade civil por uma concepção moralmente espessa atribuível

\footnotetext{
${ }^{5}$ Rawls desenvolve essa argumentação na quarte parte da sua reformulação, na sessão intitulada oportunamente Instituições de uma estrutura básica justa. Nessa, o filósofo esclarece as características constitutivas de uma democracia proprietária. Cf. RAWLS, 2002, p. 151 e ss. [2003, p. 191 e s.].
} 
a um tipo de ideal aristotélico de virtude cívica. ${ }^{6} 0$ cimento das instituições seria dado não tanto pela partilha de um mesmo horizonte jurídico, quanto por uma comunhão de intenções e de fins que derivam de uma mesma concepção da vida boa. A sedimentação e o reconhecimento dos valores da comunidade política constituiriam, em tal moldura, a síntese resolutiva e a chave para a composição dos conflitos que surgem no contexto da dimensão pública.

Segundo Bertomeu e Domènech, a tradição republicana, na acepção sustentada e promovida por eles, seria capaz de superar os limites e as questões não resolvidas pela abordagem que caracteriza o rawlsianismo metodológico e, de forma mais geral, pela perspectiva filosóficopolítica liberal. Esquematizando ao máximo a resposta republicana, é possível remodelar os quatro pontos de ruptura, individuados no paradigma rawlsiano:

1. A tradição republicana não se move em um plano traçado pelas teorias ideais;

2. A tradição republicana não põe a justiça distributiva no centro da sua atenção normativa;

3. A tradição republicana possui uma compreensão histórica e institucional das circunstâncias da justiça, como também da vida civil e política em geral;

4. A tradição republicana descende diretamente da teoria política clássica de ascendência aristotélica (sucessivamente retomada por Smith e Marx). (Cf. BERTOMEU; DOMENÉCH, 2005, p. 65-66)

O primeiro ponto evidenciado pela releitura das questões de justiça em chave republicana, dá conta da necessidade, segundo os autores contornada ou simplesmente subvalorizada pela abordagem rawlsiana, de confrontar os problemas e os conflitos surgidos dentro da dimensão pública, a partir de uma concreta descrição do contexto. 0 que a tradição republicana sugere, de fato, é que os confins das instituições devem ser desenhados pondo em seu centro as motivações plurais dos indivíduos como são e não como, idealmente, esperamos que sejam. Sobre isso, então, a exclusão de toda informação relevante é interpretada como uma redução das possibilidades de traduzir a teoria em uma práxis política que funciona concretamente.

A tradição republicana derruba ou, para melhor dizer, remodela o papel e a função da justiça distributiva. Nesse contexto, a justiça distributiva não constitui o fim último das instituições, mas representa um instrumento útil para a garantia e a implementação das liberdades

\footnotetext{
${ }^{6}$ Para um aprofundamento sobre o tema do republicanismo e das suas possíveis declinações, veja-se SKINNER, 2001; PETTIT, 2000 e BACCELLI, 2003.
} 
republicanas. Através das dinâmicas distributivas, ou redistributivas, portanto, na perspectiva do republicanismo democrático é possível estender os limites das instituições e impedir o surgimento de formas de domínio que minem a autonomia e a independência individual. Nesse sentido, o escopo é eliminar todos os obstáculos que releguem a existência de alguns a um mero estado de subsistência e de sujeição política ao querer de outros. Todavia, analisando a concepção rawlsiana, mostramos como este objetivo constitui um tema recorrente também no contexto do modelo teórico elaborado por Rawls. A noção de equidade, de fato, desenvolve-se a partir da necessidade prévia de garantir a todos a plena participação e o pleno gozo dos direitos e liberdades fundamentais.

Enfim, no que concerne ao terceiro e ao quarto ponto, o apelo à contextualização constitui um constante ponto de referência na construção do modelo institucional. 0 que o republicanismo contesta no modelo liberal é, ainda uma vez, a natureza aleatória do processo de fundação das instituições políticas. A desatenção para com a mutabilidade dos processos econômico-sociais, em nome de uma concepção ideal e geral, excessivamente geral, das relações intersubjetivas.

A indevida consideração do papel da luta de classe e das reivindicações reais e contingentes dos indivíduos, de carne e osso, determina o distanciamento das perspectivas teóricas liberais do plano real, da natureza factual e concreta das carências e das necessidades individuais.

Todavia, o risco igualmente concreto inerente a uma perspectiva como essa é que justamente o forte enraizamento no aqui e agora se revele como um ponto frágil e não como ponto forte de um modelo assim concebido. De fato, de um ponto de vista metodológico, o excesso de contextualização enfraquece a própria função normativa da dimensão política, reduzindo-a ou trazendo-a de volta ao curso de um eficientismo de teor utilitarista ou, o que seria pior, mas que representa hoje um perigo real e concreto, acabando por justificar formas protecionistas legitimadas por meras lógicas de pertença.

A tradição republicana se insere no contexto do mais amplo debate inerente à complexidade da ideia de liberdade. 0 conflito entre liberdades positivas e liberdades negativas constitui ainda hoje um exame interessante e um termo de comparação para as teorias políticas, 
mesmo se a visão, por assim dizer, estritamente dualista parece ter cedido lugar a uma interpretação mais ampla e mais articulada na qual as interseções entre âmbito individual e questões públicas redefinem os limites e os espaços de interferência.

Se, por um lado, o paradigma republicano, em todas as suas possíveis manifestações, forneceu interessantes perspectivas de reflexão úteis para uma remodelação das características gerais da relação entre indivíduos e instituições, por outro, tal perspectiva não parece capaz de dissolver de maneira coerente e razoavelmente compartilhável o nó político inerente, por exemplo, à neutralidade do Estado.

São muitas perplexidades que tal concepção levanta nesse ponto. Limitar-me-ei a assinalar aquela que considero como prioritária, também em razão da extrema conflitualidade do mundo contemporâneo e em virtude da regurgitação de nacionalismos e particularismos que dominam a cena política por todos os lados. A abordagem neorrepublicana se insere na linha de pensamento que, desde o fim dos anos 1980, determinou a passagem de uma concepção da justiça cujo escopo era mediar os conflitos entre interesses (justiça distributiva), a uma concepção na qual a mediação a que a ideia de justiça era chamada estava ligada ao reconhecimento identitário.

Penso que muitos dos problemas atuais que sacodem as instituições políticas derivem de duas perniciosas ilusões. A primeira consiste na rapidíssima liquidação das questões distributivas. A ilusória convicção de ter vencido a pobreza, de fato, deixou que as desigualdades, as formas de domínio e as políticas de exclusão social, se radicassem nas instituições e nas consciências individuais e coletivas. A segunda ilusão, estritamente ligada à primeira, é aquela segundo a qual os problemas identitários prescindem das questões distributivas e são inteiramente independentes delas. Conceber os conflitos sociais fundados sobre o reconhecimento cultura, gênero, preferência sexual - como algo que se verifica independentemente da natureza da distribuição de bens e de recursos significa aceitar culpavelmente uma visão banal e profundamente errada dos direitos. Como sublinharam Stephen Holmes e Cass Sunstein, os direitos (também aqueles prometidos e tenazmente defendidos pelos fanáticos do libertarismo) têm um preço. E tal custo é evidentemente um custo social que, em nome do princípio de solidariedade e de subsidiariedade, deve ser dividido por todos os membros da sociedade e 
particularmente por aqueles que, por efeito de uma benévola sorte moral, desfrutam de melhores condições de vida.

A sociedade não pode ser estruturada em compartimentos independentes entre si. Nesse sentido, uma concepção da justiça entendida como produto derivado (não original) da sedimentação de valores próprios de uma bem determinada concepção da vida boa, dá margem a inúmeras injustiças e abusos. Muitos dos tribunais que, espalhados no mundo contemporâneo, discursam aplaudindo irracionalmente multidões, reivindicam a titularidade de um direito de preempção sobre privilégios, liberdade e cidadania, em nome de uma concepção de justiça definida em razão de uma pertença estrita a uma comunidade de sangue, refratária de toda concepção razoável da cooperação e do respeito recíproco.

Uma concepção que nem Kant nem Rawls jamais poderiam aceitar.

\section{Bibliografia}

BACCELLI, L. Critica del repubblicanesimo. Roma-Bari: Laterza, 2003.

BERTOMEU, M. J.; DOMÈNECH, A. El republicanesimo y la crisis del rawlsismo metodológico. Isegoría, n. 33, 2005, p. 51-75.

BERTOMEU, M. J. Pobreza y propiedad. ¿Cara y Cruz de la misma moneda? Una lectura desde el republicanismo kantiano. Isegoría, n. 57, 2017, p. 477-504.

GAUTHIER, D. Morals by Agreement. New York: Oxford University Press, 1986.

HABERMAS, J. Fatti e Norme. Trad. L. Ceppa. Milano: Guerini e Associati, 1996.

HABERMAS, J. Solidarietà tra estranei. Interventi su Fatti e Norme. Trad. L. Ceppa. Milano: Guerini e Associati, 1997.

HELLER, A. Oltre la giustizia. Trad. S. Zani. Bologna: Il Mulino, 1990.

KANT, I. Idea di una storia universale dal punto di vista cosmopolitico. In KANT, I. Scritti politici. A cura di N. Bobbio, L. Firpo, V. Mathieu. Trad. G. Solari e G. Vidari. Torino: UTET, 1995.

KANT, I. La metafisica dei costumi. Roma-Bari: Laterza, 2018.

KANT, I. A metafísica dos costumes. Trad. J. Lamego. Lisboa: Calouste Gulbenkian, 2011.

MAIMONE, V. Solidarietà civica e istituzioni. In SCIACCA, F. (A cura di). La dimensione istituzionale europea. Firenze: Le Lettere, 2009, pp. 141-152.

PETTIT, P. Il Repubblicanesimo. Una teoria della libertà e del governo. Trad. P. Costa. Milano: Feltrinelli, 2000.

RAWLS, J. Giustizia come equità. Una riformulazione. Trad. G. Rigamonti. Milano: Feltrinelli, 2002.

RAWLS, J. Justiça como equidade. Uma reformulação. Trad. C. Berliner. São Paulo: Martins Fontes, 2003.

RAWLS, J. Una teoria della giustizia. Trad. U. Santini. Milano: Feltrinelli: 1989. 
RAWLS, J. Uma teoria da justiça. Trad. J. Simões. São Paulo: Martins Fontes, 2008.

RIPSTEIN, A. Force and Freedom. Cambridge; Massachusetts: Harvard University Press, 2009.

SANDEL, M. Il liberalismo e i limiti della giustizia. Trad. S. D’Amico. Milano: Feltrinelli, 1994.

SCIACCA, F. Filosofia dei diritti. Firenze: Le Lettere, 2018.

SKINNER, Q. La libertà prima del liberalismo. Trad. M. Geuna. Torino: Einaudi, 2001.

VECA, S. La filosofia politica. Roma-Bari: Laterza, 1998.

Recebido em: 09/8/2021

Aprovado em: 30/11/2021

\section{Vincenzo Maimone}

Doutor em Filosofia pela Università degli Studi di Messina (Itália).É professor Associado em Filosofia Política no Departamento de Ciências Políticas e Sociais da Università de Catania (Itália). Os seus interesses científicos se voltam às teorias da justiça e às questões em torno da igualdade. É autor de vários ensaios e artigos em revistas científicas e dos livros: La società incerta. Liberalismo, individui, istituzioni nell'era del pluralismo (2002); Which Welfare State? Which Social Policy? (2016); Democracy is the power to say "No". From Calculus of Consent to Reasonable Dissent (2018); Potere al popolo? Il paradigma della scelta colletiva e i rischi della polarizzazione (2018); La trappola dall'irrazionalità. Potere, morale e conformismo (2019) e Wonderland. Argomenti di Filosofia Politica (2021). 